\title{
Somatostatin receptor gene expression and inhibitory effects of octreotide on primary cultures of orbital fibroblasts from Graves’ ophthalmopathy
}

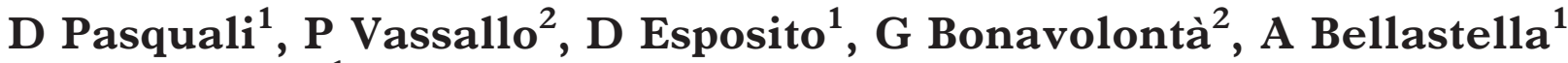 \\ and A A Sinisi ${ }^{1}$ \\ ${ }^{1}$ Istituto di Endocrinologia, Medicina Interna e Malattie della Nutrizione, Seconda Università di Napoli, \\ Naples, Italy \\ ${ }^{2}$ Istituto di Scienze Oftalmologiche, Università Federico II, Naples, Italy \\ (Requests for offprints should be addressed to A A Sinisi, Istituto di Endocrinologia, Seconda Università \\ di Napoli, Building \#16, Via Pansini 580131 Napoli, Italy; Email: Sinisi@Unina2.it)
}

\begin{abstract}
To explore the mechanism underlying the effects of the somatostatin (SST) analogue octreotide in Graves' ophthalmopathy (GO), we investigated the expression of SST and of SST receptor $\left(s s t_{1-5}\right)$ genes in primary cultures of fibroblasts established from retroorbital tissue of $\mathrm{GO}$ patients and of control subjects. We determined also SST specific binding sites by competitive binding of $\left[{ }^{125} \mathrm{I}-\right.$ $\mathrm{Tyr}^{11}$ ]SST-14 and the effect of octreotide on cell growth, cAMP accumulation, Bcl-2 intracellular levels and apoptosis in GO fibroblast primary cultures. All primary cultures expressed the SST gene transcript and one or more ssts that have a high affinity for the two analogues (class 1 sst). The $s^{s} t_{2}$ transcript was found in nine, $s s t_{3}$ in five and $s s t_{5}$ in eight out of ten GO cell cultures. $S s t_{2}$ was detected in all six, and $s s t_{3}$ in four out of the six control cell cultures. $S s t_{4}$ was absent from all samples, and $s s t_{1}$ was found only in six out of the ten GO samples.
\end{abstract}

SST-14 and octreotide inhibited the binding of $\left[{ }^{125} \mathrm{I}-\mathrm{Tyr}^{11}\right] \mathrm{SST}-14$ with a half-maximal inhibition of binding $\left(\mathrm{IC}_{50}\right)$ of $0 \cdot 80 \pm 0.37$ and $33 \cdot 7 \pm$ $33.1 \mathrm{nmol} / 1$ respectively in $\mathrm{GO}$ cell cultures, and with an $\mathrm{IC}_{50}$ of 0.9 and $1.5 \mathrm{nmol} / 1$ in control cultures. Octreotide $\left(10^{-6}\right.$ and $\left.10^{-7} \mathrm{M}\right)$ significantly decreased $(P<0 \cdot 001)$ forskolin-induced but not basal cAMP accumulation; at both doses for $72 \mathrm{~h}$ it inhibited cell growth (20 and 55\% respectively), and induced apoptosis (20 and 40\%), and abolished $\mathrm{Bcl}-2$ protein in cell lysates. In conclusion, SST and sst transcripts are expressed and functional in cultured retroorbital fibroblasts. The presence of class 1 sst in GO tissue and the inhibition exerted by octreotide on retroorbital cell growth and activity in vitro may account for the effects of SST analogue administration in vivo in GO.

Fournal of Molecular Endocrinology (2000) 25, 63-71

\section{INTRODUCTON}

Severe ophthalmopathy complicating autoimmune thyroid diseases requires aggressive treatments (i.e. immunosuppressive therapy, radiotherapy or surgical orbital decompression), but a substantial number of patients do not respond to these treatments or suffer major side-effects (Burch \& Wartofsky 1993, Gorman et al. 1994, Bartalena et al. 1997). Several clinical reports have shown that two long-acting somatostatin (SST) analogues, octreotide and lanreotide, have beneficial effects in Graves' ophthalmopathy (GO) (Chang et al. 1991, Krassas et al. 1995, 1997, Kung et al. 1996, Ozata et al. 1996), although the number of patients enrolled in the studies so far reported is too limited to allow a definitive conclusion.

The possible mechanism of action of SST analogues on GO remains unexplained (Ozata et al. 1996, Bartalena et al. 1997). Accumulation of radiolabelled SST analogue in retroorbital tissue has been demonstrated in vivo by ${ }^{111}$ In-DTPA-DPhe ${ }^{1}$-octreotide (Octreoscan) scintigraphy (Chang et al. 1991, Postena \& Krenning 1994, Kahaly et al. 1995, Krassas et al. 1995, Colao et al. 1998), suggesting the presence of specific binding sites for octreotide on the orbit components. It is not clear whether octreotide binds to retroorbital fibroblasts 
or to infiltrating immune cells. Neither is it known whether SST analogues act solely by inhibiting local immune cells or whether they also exert an effect directly on fibroblast growth and activity. SST affects target tissues through specific membrane receptors, encoded by five genes $\left(s s t_{1-5}\right)$, that display different affinities for the SST analogues used in clinical practice (Reisine \& Bell 1995, Patel 1997). Octreotide and lanreotide bind with an intermediate to high affinity to $s t_{2}, s_{s} t_{3}$ and $s s t_{5}$, which belong to the class 1 sst family. They do not show significant binding to $s s t_{1}$ and $s s t_{4}$, i.e. the class 2 sst family (Patel 1997). Functional ssts have been detected in activated human peripheral lymphocytes and in pathological and nonpathological lymphoid tissues and may play a negative regulatory role in the immune response (Lamberts et al. 1991, 1996, Van Hagen 1996). In the present study, we investigated the expression of SST and SST receptor genes in primary fibroblasts derived from retroorbital tissues of $\mathrm{GO}$ patients, and the effects in vitro of SST and octreotide on these cells.

\section{MATERIAL AND METHODS}

\section{Origin of tissues and cell cultures}

Retroorbital connective tissue was obtained from ten patients with GO during orbital decompression surgery. The diagnosis was based on endocrinological and ophthalmological criteria, including laboratory determination of hormones and antibodies and imaging studies (ultrasonography, computerized tomography or magnetic resonance scan) of orbits. The patients (seven females, three males; aged 35-68 years), euthyroid at the time of surgery, had never been treated with steroids or had been off therapy for over 6 months. Control orbital tissues were obtained from six subjects (four females, two males; aged 30-67 years) undergoing eye surgery for trauma, osteoma or strabismus. No control subject had a history of autoimmune or thyroid diseases, or was affected by orbital inflammatory conditions. Informed consent was obtained from all patients to use orbital tissue samples for in vitro study. Tissue explants were minced and placed directly in plastic culture dishes for incubation with the appropriate medium in a humidified incubator $\left(37^{\circ} \mathrm{C}, 5 \% \mathrm{CO}_{2}\right)$. Fibroblasts were allowed to proliferate in modified Eagle's medium (MEM) supplemented with L-glutamine, $10 \%(\mathrm{v} / \mathrm{v})$ foetal bovine serum and antibiotics (Gibco-BRL, Life Technologies, Milan, Italy). Four cell strains from normal and four from GO tissue specimens were used in the experimental protocols, which were repeated at least three times.

\section{mRNA isolation and reverse transcription- polymerase chain reaction (RT-PCR)}

Total RNA was isolated from the cultures at early passages (first to fourth). Total RNA was recovered with an RNAZOL B kit (Cinna/Biotecx Laboratories, Houston, TX, USA). Residual DNA was removed by RNase-free DNase I treatment (Promega, Florence, Italy). RT-PCR was carried out as previously described (Sinisi et al. 1997). RNAs were reversely transcribed using $5 \mu \mathrm{g}$ total RNA after annealing with $0 \cdot 2 \mathrm{nM}$ oligo (deoxythymidine) for priming of cDNA in the presence of reverse transcriptase (Superscript, BRL, $200 \mathrm{U}$ ) at $37^{\circ} \mathrm{C}$ for $1.5 \mathrm{~h}$. The reaction was stopped by incubation at $95{ }^{\circ} \mathrm{C}$ for $5 \mathrm{~min}$. To obtain a negative control for the amplification reactions, we carried out an RNA transcription without reverse transcriptase. Six hundred nanograms cDNA obtained by reverse transcription of RNAs were amplified in a total volume of $50 \mu \mathrm{l}$ Tris- $\mathrm{HCl}$ $10 \mathrm{mmol}, 1.5 \mathrm{mmol} \mathrm{MgCl}_{2}$ and $50 \mathrm{mmol} \mathrm{KCl} \mathrm{pH}$ $8 \cdot 3,100 \mathrm{ng}$ of primers, deoxynucleotides triphosphate $0.2 \mathrm{mmol}$ and $2.5 \mathrm{U}$ Taq DNA polymerase (Boehringer, Mannheim, Germany). A DNA thermal cycler (Perkin-Elmer/Cetus, Milan, Italy) was used for the reaction. The reaction was started by a 3 min denaturation at $95^{\circ} \mathrm{C}$; this was followed by 40 cycles of $1 \mathrm{~min}$ annealing at $60^{\circ} \mathrm{C}$, a 2 min extension at $72{ }^{\circ} \mathrm{C}$ and a $30 \mathrm{~s}$ denaturation at $95^{\circ} \mathrm{C}$. One hundred nanograms glyceraldehyde 3 -phosphate dehydrogenase (GAPDH) primers were added to each PCR reaction (25 cycles), as internal control, and the $876 \mathrm{bp}$ product of GADPH was detected in each PCR reaction. The number of cycles was chosen in the middle of the exponential phase of the reaction, separately for each type. To establish the number of cycles, GAPDH was amplified at 15, 22, 32 and 40 PCR cycles, and $s t_{1-5}$ and SST were subjected to 25 , 32,40 and 45 amplification cycles (data not shown). The 5'-3'oligonucleotides for $s s t_{1}, s s t_{2}$, $s s t_{3}, s s t_{4}$ and $s t_{5}, \mathrm{SST}$ and GAPDH are shown in Table 1. The PCR products were analysed by electrophoresis on a $1.5 \%$ agarose gel and by comparing their size with the size expected from the gene sequence. The identity of the products from representative reactions was confirmed by direct sequencing of PCR products.

The treatment with DNase and the coamplification of the GAPDH gene containing introns excluded genomic DNA contamination. Moreover, no products were detected in control amplifications 
TABLE 1. Oligonucleotide sequences used for RT-PCR

\begin{tabular}{|c|c|c|c|}
\hline & Sequence $\left(5^{\prime}-3^{\prime}\right)$ & $\begin{array}{l}\text { Size of PCR } \\
\text { product }(b p)\end{array}$ & Reference \\
\hline \multicolumn{4}{|l|}{ Gene } \\
\hline sst $_{1}$ & $\begin{array}{l}5^{\prime} \text { AGCCGGTTGACTATTACGCC } 3^{\prime} \\
5^{\prime} \text { GCTCTCACTTC }\end{array}$ & 334 & Vikic-Topic \\
\hline \multirow[t]{2}{*}{ sst $_{2}$} & $5^{\prime}$ GGTGAAGTCCTCTGGAATCC $3^{\prime}$ & 461 & Vikic-Topic \\
\hline & 5' CCATTGCCAGTAGACAGAGC 3' & & et al. (1995) \\
\hline \multirow[t]{2}{*}{ sst $_{3}$} & $5^{\prime}$ TCATCTGCCTCTGCTACCTG $3^{\prime}$ & 221 & Vikic-Topic \\
\hline & $5^{\prime}$ GAGCCCAAAGAAGGCAGGCT $3^{\prime}$ & & et al. (1995) \\
\hline \multirow[t]{2}{*}{ sst $_{4}$} & 5' CGGCAGTCTTCGTGGTCTAC 3' & 247 & Vikic-Topic \\
\hline & 5' GCATCAAGGCTGGTCACGAC 3' & & et al. (1995) \\
\hline \multirow[t]{2}{*}{ sst $_{5}$} & 5' CGTCTTCATCATCTACACGG 3' & 221 & Kubota \\
\hline & 5' GGCCAGGTTGACGATGTTGA 3' & & et al. (1994) \\
\hline \multirow[t]{2}{*}{ SST } & 5' CAGACTCCGTCAGTTTCTGCA 3' & 264 & Mato \\
\hline & $5^{\prime}$ GCTAACAGGATGTGAATGTC $3^{\prime}$ & & et al. (1998) \\
\hline \multirow[t]{3}{*}{ GAPDH } & 5' GACCCCTTCATTGACCTCAACTATG 3' & 876 & Sinisi \\
\hline & $5^{\prime}$ GTCCACCACCCTGTTGCTGTAGCC $3^{\prime}$ & & et al. (1997) \\
\hline & & & Tso \\
\hline
\end{tabular}

performed without cDNA (negative control, data not shown).

\section{Binding studies}

Cells from an early passage (first or second) were cultured in $35 \mathrm{~mm}$ diameter dishes in MEM supplemented with $10 \%$ foetal calf serum (FCS) at a density of $4 \times 10^{5} /$ dish. The cells were washed twice with Krebs/Hepes buffer, binding was performed at $25^{\circ} \mathrm{C}$ for $120 \mathrm{~min}$ in a final volume of $1.5 \mathrm{ml}$ Krebs/Hepes buffer (pH 7.4) containing $15 \mathrm{mg} / \mathrm{ml}$ BSA, $0.3 \mathrm{mg} / \mathrm{ml}$ soybean trypsin inhibitor, $0.5 \mathrm{mg} /$ $\mathrm{ml}$ bacitracin and $30 \mathrm{pM}\left[{ }^{125} \mathrm{I}_{-} \mathrm{Tyr}^{11}\right]$ somatostatin (Amersham; Milan, Italy). Non-specific binding was determined in the presence of $1 \mu \mathrm{M}$ somatostatin-14 (SST-14) (Sigma Peptides, Milan, Italy) or SMS 20-995 (Sandostatin; Novartis, Milan, Italy). The cells were then washed and lysed in $0 \cdot 1 \mathrm{M} \mathrm{NaOH}$ and specific binding was quantified. In ligand competition experiments, cells were incubated under the same conditions with $30 \mathrm{pM}$ $\left[{ }^{125} \mathrm{I}-\mathrm{Tyr}^{11}\right] \mathrm{SST}-14$ and varying concentrations of unlabelled peptide analogues.

\section{Cell proliferation assay}

Cell proliferation was evaluated with the tetrazolium salts (MTT) method. The Cell Proliferation kit (Boeringer-Mannheim) is a colorimetric assay (MTT based) for the non-radioactive quantification of cell proliferation and viability. MTT is useful for the quantification of viable cells, because only metabolically active cells cleave it to form a formazan dye (UV absorbance spectrum is between 550 and $600 \mathrm{~nm}$ ). Cells were seeded in microtitre plates in a final volume of $100 \mu \mathrm{l}$ complete culture medium at a concentration of $2 \times 10^{3}$ cells/well and grown for $24 \mathrm{~h}$ at $37{ }^{\circ} \mathrm{C}$ in $5 \% \mathrm{CO}_{2}$. Cells, starved for $24 \mathrm{~h}$ in MEM without FCS, were incubated in $1 \%$ FCS-supplemented medium with octreotide $10^{-6}, 10^{-7}$ and $10^{-8} \mathrm{M}$ or solvent (control cells) for $96 \mathrm{~h}$. Then $10 \mu \mathrm{l} \mathrm{MTT}$ solution were added to each well and plates were incubated for $4 \mathrm{~h}$. Ten microlitres of solubilization solution were added to each well and plates were kept overnight in the incubator. Absorbancy was read at $550 \mathrm{~nm}$ using a microtitre plate reader.

\section{Apoptosis detection}

The In Situ Cell Death Detection Kit (Boehringer Mannheim, TUNEL) was used to detect apoptosis and to quantify DNA strand breaks in individual cells. The cell monolayers were grown directly on sterilized slides (Superfrost; Carlo Erba, Milan, Italy), starved for $24 \mathrm{~h}$ in MEM without FCS, and then incubated in 1\% FCS-supplemented medium with octreotide $10^{-6}, 10^{-7}$ and $10^{-8} \mathrm{M}$ or solvent (control cells) for $96 \mathrm{~h}$. The slides were then fixed in buffered paraformaldehyde, permeabilized with Triton-X, and labelled with TUNEL reaction mixture according to the manufacturer's instructions. Samples were analysed using a Leitz Diaplan microscope (Leica, Milan, Italy) equipped with epifluorescence. A negative control (obtained by incubating a slide with labelled solution without terminal transferase) and a positive control 
(obtained by treating a slide with DNase I solution) were included in each assay run.

\section{cAMP production}

Confluent fibroblast monolayers in six-well plates (Costar, Milan, Italy) were starved for $24 \mathrm{~h}$ in medium without FCS, then transferred to medium supplemented with 1\% FCS and phosphodiesterase inhibitor. The cells were treated with forskolin $10 \mathrm{mM}$, octreotide $10^{-6}, 10^{-7}$ and $10^{-8} \mathrm{M}$, or forskolin plus octreotide at the indicated doses. After $30 \mathrm{~min}$, culture reactions were stopped by adding cold ethanol (70\%). After overnight incubation in ethanol, the supernatant was collected, centrifuged and dried. The extracts were reconstituted with the appropriate buffer and processed for the assay of cAMP content using an RIA kit (Amersham).

\section{Electrophoresis and Western blot analysis}

Bcl-2 protein level was evaluated by Western blot analysis of protein extracts made from three different strains of fibroblast tissue. For electrophoresis and Western blot analysis, the cells were harvested after a few minutes of incubation with PBS containing $0.2 \mathrm{mM}$ EDTA, centrifuged and the pellets containing $10^{-6}$ cells resuspended in $1: 1 \mathrm{v} / \mathrm{v}$ of denaturing lysis buffer $(2 \times)$ containing $0 \cdot 25 \mathrm{M}$ Tris- $\mathrm{HCl} \mathrm{pH} \quad 6 \cdot 8,5 \%$ SDS, $8 \mathrm{M}$ urea, $10 \mathrm{mM}$ EDTA and $0 \cdot 1 \mathrm{M}$ dithiothreitol. The cell lysates were centrifuged for $10 \mathrm{~min}$ at maximum speed $(7000 \mathrm{~g})$ at room temperature to separate DNA, after which the supernatant was boiled for a few minutes before loading on gels. Protein concentrations were normalized and equal volumes of samples were loaded on the gels. Electrophoresis was performed on $12 \%$ polyacrylamide (1:40 mono-/bis-acrylamide) containing SDS, according to standard SDS-PAGE procedures. After separation on the gel, proteins were electrophoretically transferred overnight to $0.45 \mu \mathrm{M}$ nitrocellulose sheets for Western blot analysis in transferring buffer containing $20 \%$ methanol, $10 \mathrm{~g} / 1$ glycine, $4 \mathrm{~g} / 1$ Tris and $0 \cdot 2 \mathrm{~g} / \mathrm{l} \mathrm{SDS}$. Nitrocellulose reactive groups were then blocked with Western blot buffer $(3 \mathrm{~g} / 1$ $\mathrm{Na}_{2} \mathrm{HPO}_{4}, 0.3 \mathrm{~g} / 1 \mathrm{NaH}_{2} \mathrm{PO}_{4}, 12 \mathrm{~g} / 1 \mathrm{NaCl}, 0.05 \%$ Nonidet P-40, $0.05 \%$ Tween-20) containing 4\% non-fat dried milk (Blocker; BIORAD, Rome, Italy) and $1 \% \mathrm{BSA}(\mathrm{pH} 8 \cdot 0)$. After $1 \mathrm{~h}$ of incubation with blocking solution at room temperatures, the sheets were briefly washed with Western blot buffer $(\mathrm{pH} 8.0)$ and incubated overnight and shaken at $4{ }^{\circ} \mathrm{C}$ with primary antibodies diluted in Western blot buffer containing 1\% non-fat dried milk and

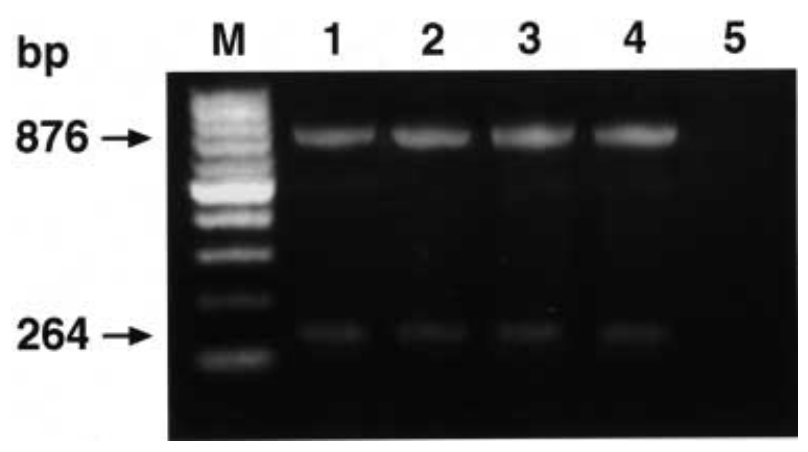

FIGURE 1. SST and GAPDH RT-PCR products, separated on a $1.5 \%$ agarose gel, obtained from cell cultures of retroorbital fat tissue of controls (lanes 1 and 2 ) and patients (lanes 3 and 4) affected by GO. SST (264 bp) and GAPDH (876 bp) mRNAs were amplified in all reactions. Lane 5 corresponds to a control RT-PCR amplification in which reverse transcriptase was excluded from the reaction. M: 100 bp DNA ladder.

$0 \cdot 25 \%$ BSA ( $\mathrm{pH} 8 \cdot 0$ ). For Bcl-2 immunoreaction we used a monoclonal antibody (BoehringerMannheim, Florence, Italy) at a working concentration of 1:800. At the end of incubation, blots were washed once for $15 \mathrm{~min}$ and three times for 5 min with Western blot buffer ( $\mathrm{pH} 8 \cdot 0)$. The antibody reaction was revealed by incubation for $45 \mathrm{~min}$ at room temperature with horseradish peroxide-coupled anti-goat or anti-mouse IgG serum (Amersham), 1:10 000 diluted in Western blot buffer ( $\mathrm{pH} 8.0)$ containing $1 \%$ non-fat dried milk and $0.25 \%$ BSA, followed by a washing cycle (as above) and using a chemiluminescent substrate (ECL; Amersham) according to the manufacturer's instructions. Visualization was by autoradiography.

\section{RESULTS}

\section{Retroorbital fibroblasts express SST and sst genes}

Both GO and control primary cultures express the SST gene: SST gene transcripts in representative GO and control primary fibroblasts are reported in Fig. 1. One or more mRNAs of the $s s t_{1}$ family (sst $t_{2}$, $s s t_{3}$ and $s s t_{5}$ ) were expressed in cultured cells from GO and control retroorbital tissues (Table 2). sst $_{2}$ transcript was found in nine GO cell cultures, and was associated with $s s t_{3}$ in five, and/or with $s t_{5}$ in eight out of the ten samples examined (see representative example in Fig. 2). sst $t_{2}$ was found in all cell cultures from control tissues, and was associated with $s_{3} t_{3}$ in three samples (see representative example in Fig. 3). Moreover, mRNAs of the 
TABLE 2. sst subtype mRNA expression in primary fibroblast cultures from retroorbital tissues

\begin{tabular}{|c|c|c|c|c|c|c|c|c|c|c|c|c|c|c|c|c|}
\hline & GO1 & GO2 & GO3 & GO4 & GO5 & GO6 & GO7 & GO8 & GO9 & GO10 & C1 & $\mathrm{C} 2$ & C3 & C4 & C5 & C6 \\
\hline \multicolumn{17}{|c|}{ Cell culture } \\
\hline sst $_{1}$ & + & + & - & + & - & + & + & - & - & - & - & - & - & - & - & \\
\hline sst $_{2}$ & + & + & + & - & + & + & + & + & + & + & + & + & + & + & + & + \\
\hline sst $_{3}$ & + & - & - & + & - & + & + & - & + & - & + & - & - & - & + & + \\
\hline sst $_{4}$ & - & - & - & - & - & - & - & + & - & - & - & - & - & - & - & \\
\hline sst $_{5}$ & + & + & + & + & + & - & + & - & + & + & - & - & - & - & - & \\
\hline
\end{tabular}

GO, Graves ophthalmopathy tissue; C, control tissue.

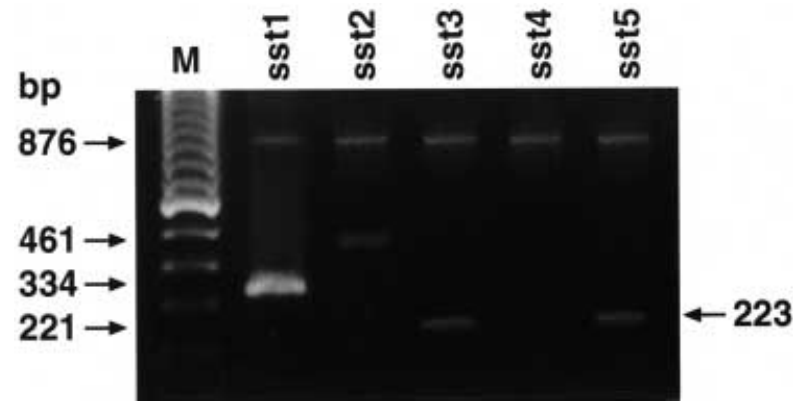

FIGURE 2. sst $_{1-5}$ and GAPDH RT-PCR products, separated on a $1 \cdot 5 \%$ agarose gel, obtained from primary cell cultures of fibroblasts from retroorbital fat tissue of a patient affected by GO. Transcripts $s s t_{1}$ (334 bp), sst $t_{2}$ $(461 \mathrm{bp}), s s t_{3}(221 \mathrm{bp})$ and $s s t_{5}(223 \mathrm{bp})$ are shown. Note that the GAPDH transcript is consistently amplified (876 bp). M: 100 bp DNA ladder.

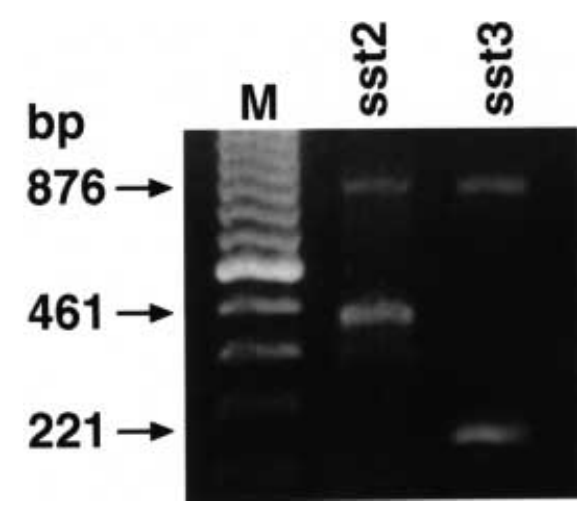

FIGURE 3. $s_{2,3}$ and GAPDH RT-PCR products, separated on a $1 \cdot 5 \%$ agarose gel, obtained from cell cultures of retroorbital fat tissue of a control patient. $s t_{2}(461 \mathrm{bp})$ and $s s t_{3}(221 \mathrm{bp})$ mRNAs are the only transcripts present; GAPDH (876 bp) is amplified in all reactions. M: $100 \mathrm{bp}$ DNA ladder.

$s s t_{2}$ family were less frequently found (Table 2): $s s t_{1}$ transcript was found in five out of the ten GO samples (see representative example in Fig. 2); sst was absent from all samples (see representative examples in Figs 2 and 3).

\section{GO and control primary cell cultures bind $\left[{ }^{125} \mathrm{I}-\mathrm{Tyr}{ }^{11}\right] \mathrm{SST}-14$}

Three primary cultures studied displayed specific

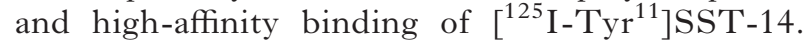
Competitive displacement by unlabelled analogues showed that the half-maximal inhibition of binding was (mean \pm s.E.M.) $0 \cdot 80 \pm 0 \cdot 37 \mathrm{nmol} / 1$ for SST-14 and $33 \cdot 7 \pm 33 \cdot 1$ for octreotide in $\mathrm{GO}$ cell cultures, and 0.9 for SST -14 and $1.5 \mathrm{nmol} / 1$ for octreotide in a control fibroblast culture.

\section{In vitro effects of octreotide}

GO fibroblast cultures treated with octreotide $\left(10^{-6}\right.$ and $10^{-7} \mathrm{M}$ ) for $72 \mathrm{~h}$ showed a cell growth inhibition (50 and $35 \%$ respectively) (Fig. 4 ), and significantly decreased $(P<0.001)$ forskolin-induced but not basal cAMP accumulation (Fig. 5). Nuclear DNA fragmentation occurred in 40 and $20 \%$ of cells exposed to $10^{-6}$ and $10^{-7} \mathrm{M}$ octreotide for $72 \mathrm{~h}$ (Fig. 6).

\section{Bcl-2 protein levels}

We determined whether $\mathrm{Bcl}-2$ proteins were present in fibroblast from $\mathrm{GO}$ retroorbital tissue and whether their levels changed following octreotide administration. Bcl-2 protein, detected in basal conditions, was abolished after octreotide treatment (Fig. 7).

\section{DISCUSSION}

We demonstrate that SST and its receptor genes are transcribed in primary fibroblast cultures from retroorbital tissues. We also show that retroorbital fibroblasts specifically bind SST-14, and respond in vitro to the SST analogue octreotide by inhibition of cAMP production and cell growth. The presence of functional ssts on retroorbital tissues of patients with GO was suggested by the uptake of ${ }^{111} \mathrm{In}$ DTPA-D-Phe ${ }^{1}$-octreotide into the orbits during the 


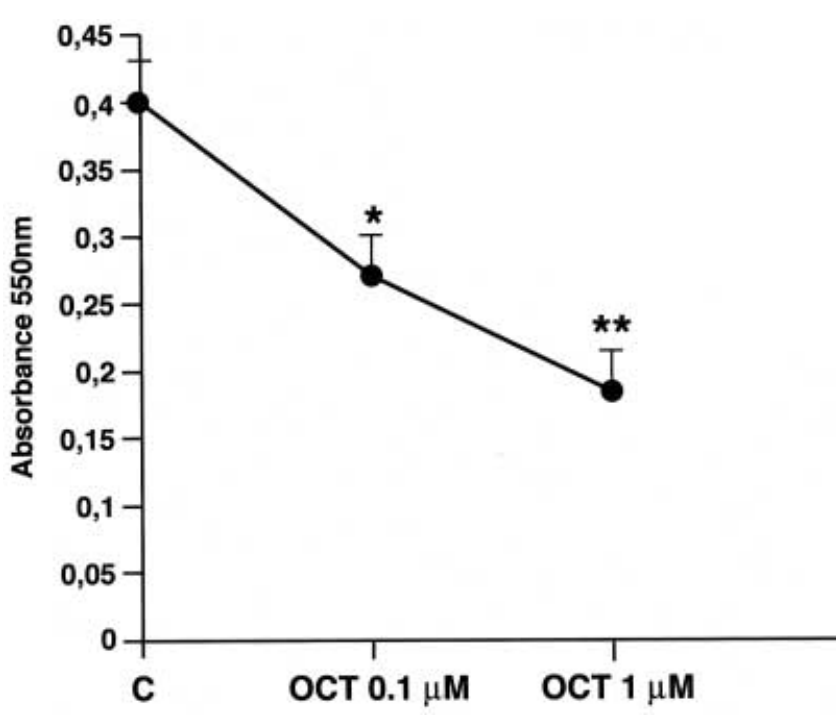

FIGURE 4. Octreotide-induced growth inhibition of cell cultures from retroorbital fat tissue of patients affected by GO. The cells were seeded at 2000 cells per well and treated with $10^{-6} \mathrm{M}$ and $10^{-7} \mathrm{M}$ octreotide (OCT) for $72 \mathrm{~h}$. The results were expressed as the $\mathrm{A}_{550}$ of MTT-derived formazan developed by untreated control (C) and treated cells. Each point represents the mean \pm s.E. of three separate experiments $(* P<0 \cdot 05$; *** $P<0 \cdot 0005)$.

active phase of the disease (Chang et al. 1991, Postena \& Krenning 1994, Kahaly et al. 1995, Krassas et al. 1995, Colao et al. 1998). The retroorbital infiltrating immune cells, which harbour SST receptors, have been implicated in this

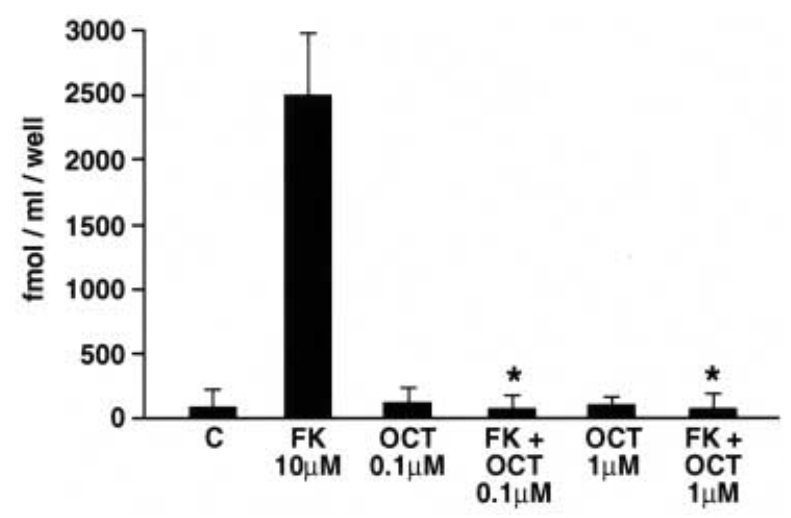

FIGURE 5. Octreotide-induced inhibition of forskolin (FK)-stimulated cAMP accumulation in cell cultures from retroorbital fat tissue of patients affected by GO. The cells were treated with FK $10 \mu \mathrm{M}$ with or without octreotide (OCT) $10^{-6} \mathrm{M}$ and $10^{-7} \mathrm{M}$ for $30 \mathrm{~min}$. Each column represents the mean \pm s.E. of three separate experiments $(* P<0 \cdot 001$ versus $\mathrm{FK}$-stimulated cAMP accumulation). uptake, but unfortunately SST receptor imaging in vivo does not distinguish the particular cells to which the labelled analogue binds (Reubi 1994). In the present study at least one of the genes coding for known SST receptor subtypes with high $\left(s s t_{2}\right)$ or with intermediate (sst $t_{3}$ and $s s t_{5}$ ) affinity for the analogue octreotide appears to be expressed on GO retroorbital fibroblasts. Using competitive binding of $\left[{ }^{125} \mathrm{I}-\mathrm{Tyr}^{11}\right] \mathrm{SST}-14$, primary fibroblast cultures displayed a high affinity for SST-14 and a variable (intermediate to high) affinity for octreotide, suggesting that functional receptor proteins are present on cell membranes. Consequently, it appears that the uptake of labelled octreotide in the orbits of GO subjects in vivo may be due to specific binding to connective tissue elements and that octreotide and lanreotide may interact directly with retroorbital fibroblasts. Thus SST analogues control clinical manifestations of GO acting on immune cells infiltrating the orbits and probably on retroorbital fibroblasts.

The natural SST peptide and its stable analogues negatively regulate the growth and activity of several normal and deranged cells, including cancer cells, via specific receptor subtypes and receptorcoupled intracellular signals (Reisine \& Bell 1995, Patel 1997). Octreotide, at physiological concentrations, inhibited cAMP accumulation in vitro, demonstrating that, as in other cell systems (Patel 1997), ssts in retroorbital fibroblasts are negatively coupled to adenyl-cyclase activity. In addition, octreotide significantly inhibited cell proliferation and induced signs of cell apoptosis associated with a pronounced dose-dependent inhibition of $\mathrm{Bcl}-2$ protein levels, which was maximal after $72 \mathrm{~h}$ of treatment. Octreotide controls cell growth through subtype-specific signals: $s s t_{2}$ appears to be the main mediator of the tyrosine phosphatases-induced inhibition of growth factor phosphorylation; sst acts via the induction of retinoblastoma protein $\mathrm{Rb}$ and G1 cell cycle arrest; sst ${ }_{3}$ seems to mediate the cytotoxic effects of SST analogues so inducing apoptosis (Sharma et al. 1996, 1999, Patel 1997, Florio et al. 1999). The presence of both cytostatic and cytotoxic effects suggests that intracellular signal transduction pathways activated by octreotide coupling to $s s t_{2}, s s t_{3}$ and $s s t_{5}$ are functional in the retroorbital fibroblasts.

The evidence of coexpression of SST and sst genes in cultured retroorbital fibroblasts suggests that the somatostatinergic system is involved in the local control of the growth and activity of retroorbital cells in both physiological and pathological conditions. The pathogenesis of $\mathrm{GO}$ is unknown, but it is generally considered an extra-thyroidal manifestation of an autoimmune 

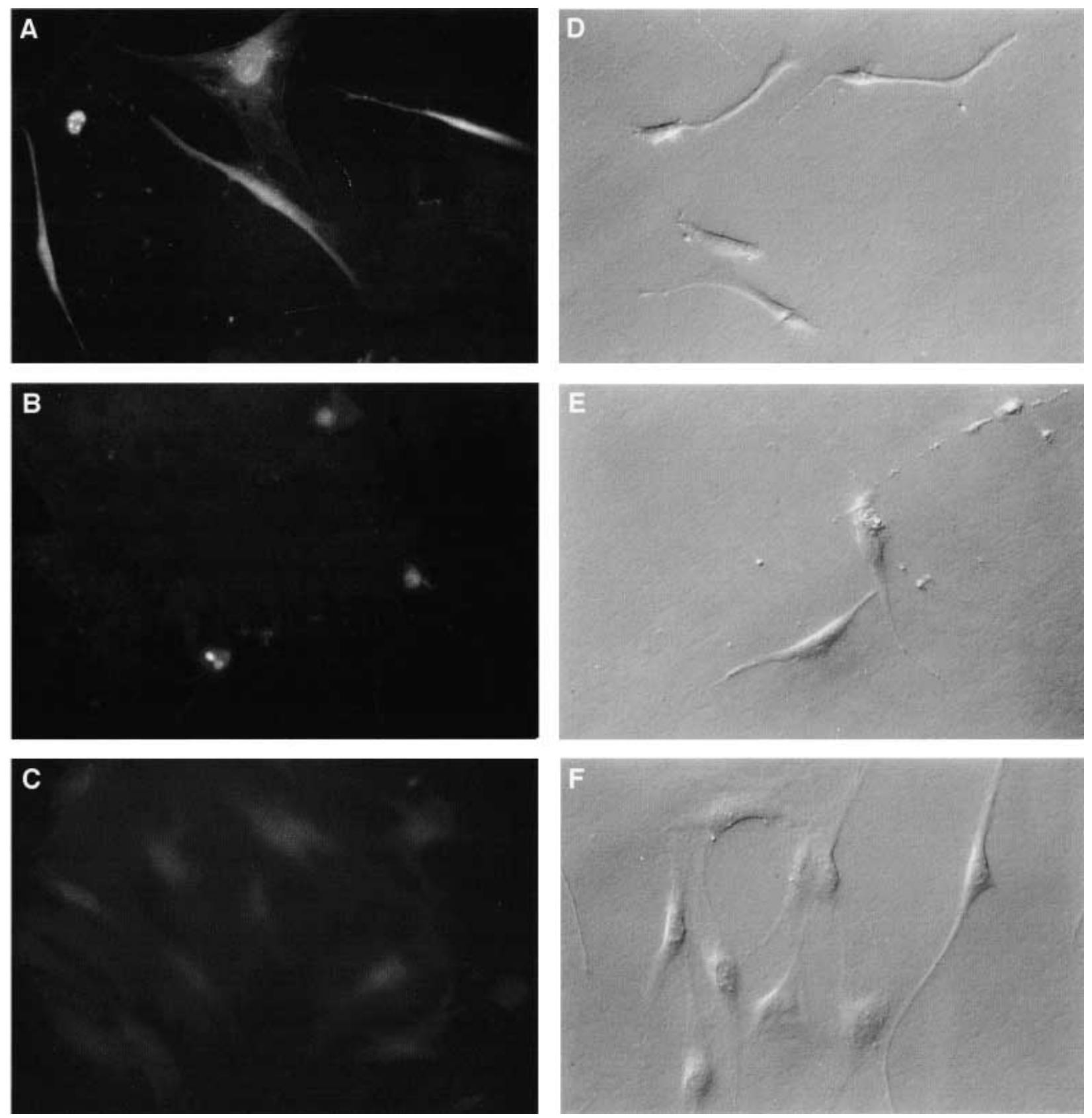

FIGURE 6. TUNEL staining (A, B) and phase contrast (D, E) showing apoptotic cells in primary cultures from retroorbital fat tissue of patients affected by GO after $96 \mathrm{~h}$ of treatment with $10^{-7} \mathrm{M}(\mathrm{A}, \mathrm{D})$ and $10^{-6} \mathrm{M}(\mathrm{B}, \mathrm{E})$ octreotide respectively. (C, F) Untreated controls. Magnification: $\times 500$.

process directed against an antigen common to thyroid and orbital tissue (Bahn \& Heufelder 1993, Burch \& Wartofsky 1993, Heufelder 1997). Experimental evidence suggests that thyrotrophin receptor (TSR), is expressed in retroorbital adipocytes, and may be one of the possible antigens stimulating the auto-antibodies implicated in prolif-

www.endocrinology.org erative changes of retroorbital tissues in GO (Bahn \& Heufelder 1993). Since the SST system is involved in counteracting TSR-mediated effects on the cell cycle in thyroid cells (Medina et al. 1999), we can speculate that an autocrine loop between SST, ssts and TSR might operate in retroorbital cells and might be defective in GO.

Fournal of Molecular Endocrinology (2000) 25, 63-71

Downloaded from Bioscientifica.com at 04/26/2023 01:24:23PM 


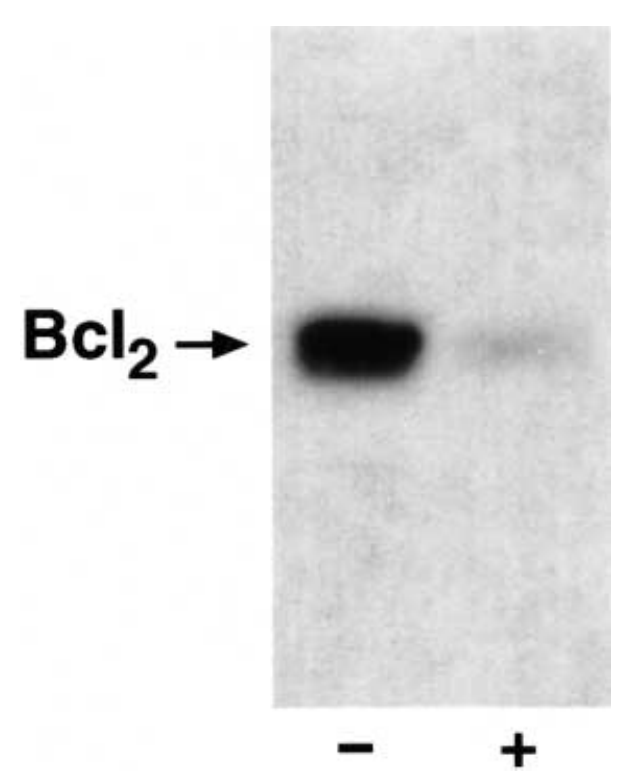

FIGURE 7. Western blot analysis of Bcl-2 protein expression in cell lysate of fibroblasts from GO retroorbital tissue before (lane 1) and after $72 \mathrm{~h}$ (lane 2) of $10^{-6} \mathrm{M}$ octreotide treatment.

In conclusion, we found that cultured retroorbital fibroblasts expressed the SST gene together with all the $s s t$ subtypes $\left(s s t_{2}, s s t_{3}\right.$ and $\left.s s t_{5}\right)$ that are required for the negative cell growth signal, and that bind the synthetic SST analogues currently used in clinical practice. Moreover, we demonstrate that octreotide inhibits in vitro growth and activity of retroorbital fibroblasts from GO patients, a process that could explain, in addition to the possible immune system inhibition, the reported effects of in vivo administration of SST analogues in these subjects.

\section{ACKNOWLEDGEMENTS}

This work was supported in part by funds from Associazione Italiana Ricerca Cancro (AIRC 1996) to A A S and Ministero Università e Ricerca Scientifica e Tecnologica (MURST 60\%) to A B.

\section{REFERENCES}

Bahn RS \& Heufelder AE 1993 Mechanisms of disease: pathogenesis of Graves' ophthalmopathy. New England Fournal of Medicine 239 1468-1475.

Bartalena L, Marcocci C \& Pinchera A 1997 Treating severe Graves' ophthalmopathy. Ballière's Clinical Endocrinology and Metabolism 3 521-536.

Burch HB \& Wartofsky L 1993 Graves' ophthalmopathy: current concepts regarding pathogenesis and management. Endocrine Reviews 14 747-793.
Chang TC, Kao SCS \& Huang KM 1991 Octreotide and Graves' ophthalmopathy and pretibial myxoedema. British Medical fournal 304158.

Colao A, Lastoria S, Ferone D, Pivonello R, Macchia PE, Vassallo P, Bonavolonta G, Muto P, Lombardi G \& Fenzi G 1998 Orbital scintigraphy with $\left[{ }^{111}\right.$ In-diethylenetriamine pentaacetic acid-D-Phe ${ }^{1}$ ]-octreotide predicts the clinical response to corticosteroid therapy in patients with Graves' ophthalmopathy. Fournal of Clinical Endocrinology and Metabolism 83 3790-3794.

Florio T, Yao H, Carey KD, Dillon TJ \& Stork PhJS 1999 Somatostatin activation of mitogen-activated protein kinase via somatostatin receptor 1 (SSTR1). Molecular Endocrinology 13 24-37.

Gorman CA, Heufelder AE \& Bartley GB 1994 Ophthalmopathy. In Endocrinology, pp 712-725. Ed. LJ De Groot. Philadelphia: Saunders.

Heufelder AE 1997 Retro-orbital autoimmunity. Baillière's Clinical Endocrinology and Metabolism 11 499-520.

Kahaly G, Diaz M, Just M, Beyer J \& Lieb W 1995 Role of octreoscan and correlation with imaging in Graves' ophthalmopathy. Thyroid 5 107-111.

Krassas G, Dumas A, Pontikides N \& Kaltsas T 1995 Somatostatin receptor scintigraphy and octreotide treatment in patients with thyroid eye disease. Clinical Endocrinology 42 $571-580$.

Krassas GE, Kaltsas T, Dumas A, Pontikides N \& Tolis G 1997 Lanreotide in the treatment of patients with thyroid eye disease. European Fournal of Endocrinology 136 $416-422$

Kubota A, Yamada Y, Kagimoto S, Shimatsu A, Imamura M, Tsuda K, Imura H, Seino S \& Seino Y 1994 Identification of somatostatin receptor subtypes and an implication for the efficacy of somatostatin analogue SMS 201-995 in treatment of human endocrine tumors. Fournal of Clinical Investigation 93 1321-1325.

Kung AWC, Michon J, Tai KS \& Chan FL 1996 The effect of somatostatin versus corticosteroid in the treatment of Graves' ophthalmopathy. Thyroid 6 381-384.

Lamberts SWJ, Krenning EP \& Reubi JC 1991 The role of somatostatin and its analogs in the diagnosis and treatment of tumors. Endocrine Reviews 12 450-482.

Lamberts SWJ, Van Der Lely A-J, De Herder WW \& Hofland LJ 1996 Octreotide. New England Fournal of Medicine 334 246-254.

Mato E, Matias-Guiu X, Chico A, Webb SM, Cabezas R, Bernà LL \& De Leiva A 1998 Somatostatin and somatostatin receptor subtype gene expression in medullary thyroid carcinoma. Fournal of Clinical Endocrinology and Metabolism 88 2417-2420.

Medina DL, Velasco JA \& Santisteban P 1999 Somatostatin is expressed in FRTL-5 thyroid cells and prevents thyrotropin-mediated down-regulation of the cyclin-dependent kinase inhibitor p2 $7^{\mathrm{kip} 1}$. Endocrinology 140 $87-95$.

Ozata M, Bolu E, Sengul A, Tasar M, Beyhan Z, Corakci A \& Gundogan A 1996 Effects of octreotide treatment on Graves' ophthalmopathy and circulating sICAM-1 levels. Thyroid 6 283-288.

Patel YC 1997 Molecular pharmacology of somatostatin receptor subtypes. Fournal of Endocrinological Investigation 20 348-367.

Postena PTE \& Krenning EP 1994 (111-In-DTPA-D-Phe)octreotide scintigraphy in thyroid and orbital Graves' disease: a parameter for disease activity? Fournal of Clinical Endocrinology and Metabolism 79 1845-1851.

Reisine T \& Bell GI 1995 Molecular biology of somatostatin receptor. Endocrine Reviews 16 427-442. 
Reubi JC 1994 Invited commentary. Clinical relevance of somatostatin receptor imaging. European Fournal of Endocrinology 131 575-576.

Sharma K, Patel YC \& Shrikant CB 1996 Subtype-selective induction of wild-type p53 and apoptosis, but not cell cycle arrest, by human somatostatin receptor 3. Molecular Endocrinology 10 1688-1696.

Sharma K, Patel YC \& Shrikant CB 1999 C-terminal region of human somatostatin receptor 5 is required for induction of $\mathrm{Rb}$ and G1 cell cycle arrest. Molecular Endocrinology 13 82-90.

Sinisi AA, Bellastella A, Prezioso D, Nicchio MR, Lotti T, Salvatore M \& Pasquali D 1997 Different expression patterns of somatostatin receptor subtypes in cultured epithelial cells from human normal prostate and prostate cancer. Fournal of Clinical Endocrinology and Metabolism 82 2566-2569.
Tso JY, Sun X-H, Kao T, Reece KS \& Wu R 1985 Isolation and characterization of rat and human glyceraldehyde-3-phosphate dehydrogenase cDNAs: genomic complexity and molecular evolution of the gene. Nucleic Acids Research 13 2485-2502.

Van Hagen PM 1996 Somatostatin receptor expression in clinical immunology. Metabolism 8 (Suppl 1) 86-87.

Vikic-Topic S, Raisch KP, Kvols LK \& Vuk-Pavlovic S 1995 Expression of somatostatin receptor subtypes in breast carcinoma, carcinoid tumor, and renal cell carcinoma. Fournal of Clinical Endocrinology and Metabolism 80 2974-2979.

REVISED MANUSCRIPT RECEIVED 3 March 2000 